This is an Accepted Manuscript of an article published by Taylor \& Francis in Journal of Gender Studies on $27^{\text {th }}$ March, 2012, available online: http://www.tandfonline.com/ 10.1080/09589236.2012.639176

\title{
Representation of masculinities and race in South African television advertising: a content analysis
}

R. Luyt*

Department of Psychology, University of Winchester, Winchester, UK

\begin{abstract}
This paper examines how masculinities and race are co-constructed in South African television advertising. A sample of 5803 advertisements was collected that included 876 primary visual male actors. These were coded and analysed by means of traditional content analysis. A coding scheme was developed which was partly based on existing research. Coding categories included advertisement setting and products; race, social class, age and portrayal of primary visual actor; as well as sexuality, toughness, independence, status, responsibility and homophobia norms of traditional masculinity as related to the primary visual male actor. Hypotheses predicted that men would be represented significantly differently in television advertisements depending upon their race. These differences in representation reflect an intersection between traditional gender and race relations in South Africa that are marked by longstanding inequalities. The findings largely supported these hypotheses. White men are represented as exemplars of hegemonic masculinity whilst black men are marginalised. It is argued that these representations serve to maintain hierarchical social relations between men in South Africa. This study provides a foundation upon which further work may be undertaken. Avenues for future research are outlined.
\end{abstract}

Keywords: masculinity; masculinities; race; representation; South Africa; television advertising

This paper seeks to examine how masculinities are represented in South African (SA) television advertising. It is anticipated that men are represented differently in television advertisements depending upon their race. These differences reflect an intersection between traditional gender and race relations in society. ${ }^{1}$ Few studies consider how media representations of gender intersect with other social categories (e.g. Coltrane and Messineo 2000). Likewise a limited number of studies examine gender (e.g. Furnham and SpencerBowdage 2002, Milner 2005) or race (e.g. Milner 2007) representation in SA television advertising. The current study attempts to address this gap in the literature. A content analysis of SA television advertising provides a useful means through which to examine the co-construction of masculinities and race at a regional or national level.

Both Gender and race relations in SA have traditionally been marked by extreme inequality. Gender inequality is evident through measures such as the Gender-Related Development Index (GDI), which ranks SA 109th worldwide in terms of gender equalitarianism (United Nations Development Programme 2009), but is also apparent in literature testifying to traditionalist gender attitudes (Kalichman et al., 2005, Luyt 2005) and discourses (Luyt 2003, Reddy and Dunne 2007). Burns (1998) observes how the imported colonial as well as the indigenous African gender systems have served to reinforce and naturalise traditional gender relations in the country.

Similarly race inequality is obvious through measures such as the Human Development Index (HDI) where large inter-group differences appear. The white population group exhibits the highest HDI, indicating a high level of human development, whereas the black African population group exhibits the lowest HDI pointing towards medium to low human development (Statistics South Africa 2007a). Such inequality is a product not only of legalised discrimination during Apartheid but also through centuries of colonial rule and accompanying dispossession as well as structural discrimination on the basis of race (Feinstein 2005). 
Socio-political change has served to challenge the status quo in SA over the last two decades. Change was, perhaps, most visible in the transition to majority political rule that culminated in democratic elections in 1994. Yet, despite these changes, power still remains unevenly distributed in a highly stratified society. Inequitable ownership and access to social, economic and political resources prevail across gender and race.

A social constructionist perspective is adopted in the current study (see West and Zimmerman 1991, Bohan 1993, Brannon 1999) in order to examine the co-construction of masculinities and race. This theoretical perspective is considered best suited to the task. Emphasis is placed, in particular, on the concept of hegemonic masculinity (Carrigan et al., 1985, Connell 1987, 1993, 1995, 2000, 2002, Connell and Messerschmidt 2005). This concept has encouraged a wealth of empirical literature (e.g. Bird 1996, Wetherell and Edley 1999, Luyt and Foster 2001) including research focusing on media (e.g. Trujillo 1991, McKay and Middlemiss 1995, Clarke 1999). Its broad theoretical critique is also well documented (e.g. Demetriou 2001, Hall 2002, Jefferson 2002, Wilkinson 2004), bearing witness to its profound and enduring cross-disciplinary impact.

Hegemonic masculinity was originally defined “"as” the configuration of gender practice which embodies the currently accepted answer to the problem of the legitimacy of patriarchy, which guarantees (or is taken to guarantee) the dominant position of men and the subordination of women' (Connell 1995, p. 77). It therefore refers to a dominant, socially admired and historically contingent pattern of gender practice. This serves the interests of powerful men through legitimating and maintaining patriarchal gender relations. These relations are not only characterised by men's dominance over women but also hierarchy between men (Carrigan et al., 1985). In SA, for example, one might expect to see the ascendance of white men over black men. Hierarchical relations between men have been described through terms such as complicit, subordinated and marginalised masculinities (Connell 1987, 2000) and are often determined along axes of social difference such as race, sexuality and social class (Connell 2002). Luyt (2003), for example, suggests that the currently idealised version of masculinity in SA emphasises the importance of: control, (un)emotionality, physicality and toughness, competition, success, (hetero)sexuality, and responsibility.

Media are argued to act as an important cultural process through which a particular version of masculinity achieves as well as maintains hegemony (Carrigan et al., 1985). Their representation of masculinity suggests ways in which men may practise gender. A distinction therefore exists between the processes of representation and practice. Gender representation occurs at a cultural or ideological level. It takes shape through language 
This is an Accepted Manuscript of an article published by Taylor \& Francis in Journal of Gender Studies on $27^{\text {th }}$ March, 2012, available online: http://www.tandfonline.com/ 10.1080/09589236.2012.639176

or other symbolic forms and offers shared ways of understanding. Gender practice is made possible through such representation. It occurs at an individual, interpersonal and institutional level. This study describes a process of representation. It is important to underline that these two processes reciprocally inform one another. A number of theories exist to explain media effect [e.g. the social cognitive theory of mass communication (Bandura 2001), agenda-setting theory (McCombs and Shaw 1972), etc.]. Yet the centrality model of communication content (Riffe et al., 1998) succinctly illustrates the reciprocity between gender representation and practice as it applies to the study of television advertising.

The model suggests that communication content emerges as a result of antecedent conditions - including, for example, cultural, political, psychological and social factors and at the same time affects these. It also underlines that antecedent conditions and effect are frequently assumed rather than demonstrated in research surrounding communication content. This is the case in the current study, although avenues for future research are discussed at a later stage.

Although interest in masculinity and its relationship to media first surfaced as early as the 1970s, it is only recently that media research has actively attempted to problematise their relationship concept. It is claimed that research has adopted one of two theoretical explanations of gender: the sex role or social constructionist perspective (Hanke 1998). Whilst this distinction may variably suggest different methodological choices, it holds unavoidable implications for the interpretation of findings. Clear articulation of, and justification for, one's adopted theoretical perspective is therefore necessary.

The sex role perspective has dominated empirical mass communication research for more than four decades (Craig 1992a). This research is frequently motivated by what Wilkinson (2001, p. 18) has called feminist positivist empiricism. She suggests that this favours the use of "“conventional" scientific methods ... to produce "factual” knowledge about an objectively present, and so observable and measurable, external world'. It therefore attempts to describe the portrayal of men and women, as well as to determine its effect, through the analysis of manifest media content. From this perspective, femininity and masculinity exist as fact, waiting to be observed, described and explained (Fejes 1992).

The social constructionist perspective has emerged as a viable theoretical alternative. Media research undertaken from within this perspective is often motivated by feminist social constructionism. This takes “"the” view that "facts” are always dependent on the particular forms of language and the particular language communities which have created and maintained them'. Therefore " "we" cannot "know" the external world ... or the internal world because all knowledge is mediated by - indeed, constructed through - the specificities of language' (Wilkinson 2001, p. 24). Particular emphasis is afforded the problematisation of masculinity which is achieved through understanding its social construction (Craig 1992a, Fejes 1992, Hanke 1992). This emphasis has been encouraged by 'men's studies' (Craig 1992a) and it is argued that it represents a major development in current feminist media research (Watkins and Emerson 2000).

Existing research concerning the social construction of masculinity within media has explored a range of important questions. These include: what function do media perform in defining masculinity; how are men's relationships to other men represented; what function do media perform in reinforcing men's dominance and power; how do men respond to mediated representations of masculinity; how do men actively interpret these; and what effect do they have, specifically in relation to identity, subjectivity and experience (Craig 1992a, Hanke 1998)? These questions have been applied in the study of various media types. 
This is an Accepted Manuscript of an article published by Taylor \& Francis in Journal of Gender Studies on $27^{\text {th }}$ March, 2012, available online: http://www.tandfonline.com/ 10.1080/09589236.2012.639176

A selective review of research in the field includes, for example, Conekin's (2000) work that credits Playboy magazine as contributing to the construction of a particular version of masculinity in the United States during the early 1950s and 1960s; Boni's (2002) study that similarly attempts to explain the recent and growing popularity of men's lifestyle magazines through an analysis of the Italian edition of Men's Health; and Hodgetts and Chamberlain's (2002) research that explores how men construct their understanding of health through media representations. Social constructionist emphasis on audience interpretation illustrates, in particular, its divergence from the sex role perspective.

Sex role research has, in contrast, demonstrated that media most often portray gender through traditional stereotypes. These are argued to play an important role in the process of sex typing (Fejes 1992). However, audience interpretation research throws this assumption into question. Rather than, for example, serving as symbolic models, interaction between media characters is seen to " "provide" a diffuse confirmation of one's world view, promote acceptance of current social arrangements, and reassure people that things are the way they ought to be' through a particular interpretive lens. It also crucially serves to inform gender practice. Thus media representations construct femininity and masculinity in a fashion that maintains hierarchical gender relations (Coltrane and Messineo 2000, p. 364) over time and context. Variability in gender representations across sites, such as industry and genre, provides evidence of this process (Watkins and Emerson 2000).

The concept of hegemonic masculinity is argued to afford a useful tool with which to explore how masculinity is constructed through media representation and practices so as to maintain men's dominance within the gender order (Hanke 1992). McKay and Middlemiss's (1995) study, for instance, illustrates nicely how hegemonic masculinity in Australia is (re)produced through media coverage of rugby league. Athletes are represented as warrior-heroes who engage each other on a venerated battlefield. This representation not only defines 'real masculinity' but also contributes toward solidifying local and regional identities - in this case the regional identity of the 'deep north'.

Strate (1992) similarly explores the construction of dominant masculinity through an analysis of beer advertisements on television. Collectively these are said to offer a 'manual on masculinity' and do so through (re)producing traditional gender representations; but research of this kind is limited. A review of the empirical literature suggests that most research has only addressed the way in which masculinity is constructed by the North American media (Craig 1992a). It is important to investigate the construction of masculinity in other regional contexts. Moreover, few studies have considered how gender representations in media intersect with other social constructs, such as race. Coltrane and Messineo (2000) offer a rare example in their consideration of intersecting gender and race representation.

These authors describe how gender and race are co-constructed by television advertising. They, somewhat unusually, make use of content analytic procedures in order to do so. This method of analysis ordinarily features in research that adopts the sex role perspective, yet their analysis of 1699 television advertisements is informative. Findings suggest that, in general, white men were portrayed as powerful; white women as sex objects, domesticated and romantically successful; black African men as aggressive; and black African women as inconsequential. These representations are said to reinforce subtle prejudice against women in general and African Americans in particular.

This study similarly describes how masculinities and race are co-constructed in SA television advertisements. Research of this kind has yet to be undertaken in the country and provides fertile ground upon which further analyses can be undertaken. Media construct and represent gender in a fashion that maintains hierarchical social relations, not only between men and women, but also between men. Content analysis provides a useful 
This is an Accepted Manuscript of an article published by Taylor \& Francis in Journal of Gender Studies on $27^{\text {th }}$ March, 2012, available online: http://www.tandfonline.com/ 10.1080/09589236.2012.639176

analytic method with which to explore the extent to which men are represented significantly differently in television advertisements depending upon their race. These differences are expected to reflect an intersection between traditional gender and race relations in SA that are marked by longstanding inequalities. The following hypotheses are examined:

H1: White men will be represented as primary visual actors significantly more frequently than black men.

H2: $\quad$ White men will be represented significantly more frequently as of higher socioeconomic status than black men, who will be represented significantly more frequently as being of lower socio-economic status.

H3: White men will be represented significantly more frequently within older age groups, which are traditionally viewed as being of higher status, than black men who will be represented significantly more frequently within younger age groups, which are traditionally viewed as being of lower status.

H4: White men will be portrayed significantly more positively than black men who will be portrayed significantly more negatively.

H5: White men will be represented significantly more frequently in settings away from home, which are traditionally viewed as being masculine, than black men, who will be represented significantly more frequently in home settings, which are traditionally viewed as being feminine.

H6: White men will be associated significantly more frequently with products such as vehicles, which are traditionally viewed as masculine, whereas black men will be associated significantly more frequently with products such as domestic goods, which are traditionally viewed as feminine.

H7: White men will appear significantly more frequently as successful in accomplishing traditional masculinity than black men who will appear significantly more frequently as unsuccessful in accomplishing traditional masculinity.

H8: Black men will appear significantly more frequently as successful in accomplishing alternative masculinity than white men who will appear significantly more frequently as unsuccessful in accomplishing alternative masculinity.

\section{Method}

Sample

It has long been argued that the analysis of television advertisements is important given their pervasiveness in society (McArthur and Resko 1975). This is the case in SA although perhaps not to the same extent as in developed countries. Television is available in $65.6 \%$ of households (Statistics South Africa 2007b), yet a clear disparity emerges across population groups: $94.7 \%$ of white headed households have access to television. Likewise a high proportion of Asian (i.e. 91\%) and coloured (i.e. 75.3\%) headed households also possess television. The comparatively low average percentage of households nationally that have access to television may be explained as a result of the low proportion of black African headed households that possess one (i.e. 44.2\%) (Statistics South Africa 2003). It is nonetheless likely that access to television will steadily increase across all population groups in line with socio-economic development. This, together with the fact that similar existing studies favour the use of television data as a means to assess visual representation, suggests it is worthwhile in the current study.

Television advertisements served as the sampling unit. They were recorded from all free-to-air channels available in the country. These included SABC 1, 2, 3 and E-TV. 
This is an Accepted Manuscript of an article published by Taylor \& Francis in Journal of Gender Studies on $27^{\text {th }}$ March, 2012, available online: http://www.tandfonline.com/ 10.1080/09589236.2012.639176

Data collection took place over a four week period from 20 February to 19 March 2003. A stratified sampling procedure was adopted through the use of a method known as the constructed or artificial week (Bauer 2000, Riffe et al., 1998). This method involved developing a sampling frame that stratified every day, over a specified period, into eight day parts or time periods. These were each three hours in length. The inclusion of day part in the sampling procedure was considered especially important in this study. Research indicates that representations of gender differ according to the day part (e.g. Craig 1992b). Random selection, without replacement of day parts, then took place. This continued until each day part under a specific day of the week had been selected. A number of day parts were re-sampled over a week period from 10 March to 16 March 2003. This was due to either signal or equipment failure.

A total of 5803 advertisements were recorded. These were edited under channel, as well as day of the week, and then catalogued. Repeated advertisements were included whereas channel self-promotional advertisements and competitions were excluded. Debate exists as to whether repeated advertisements should be included in the analysis or not (see Craig 1992b, Moon and Chan 2002, Ganahl et al., 2003). This study agrees with Ganahl et al. (2003, p. 547) who argue that repeated advertisements should be "“coded” because the process accurately exemplifies cultural cultivation via repetitive images', an argument consistent with cultivation theory (Gerbner and Gross 1976). Some 876 advertisements contained primary visual male actors and were included in the current analysis.

\section{Procedure}

Content analysis is a useful means by which to describe communication content as well as to trace changes over time. It enables researchers to reduce the complexity of a large body of material in order to extract useful information. The method features particularly prominently in mass communication research (Neuendorf 2002, Joffe and Yardley 2003) and implicitly reflects the key assumptions contained within the centrality model of communication content. Thus, Craig (1992a, p. 198) notes, “"(w)hile” content analysis is limited in the information it can provide about television gender representations, it can and should provide the essential starting point for further critical analysis'.

Some critical researchers may disagree with this statement. This disagreement primarily stems from epistemological concerns. It frequently expresses itself as a debate surrounding whether or not content analysis should be considered to be a quantitative as opposed to a qualitative method (Berg 1998). Wilkinson (2001) correctly observes that content analysis has commonly been used as a means by which to analyse qualitative data from within a positivist empiricist framework. In these cases it is treated as a quantitative method that is believed to render objective results in the form of frequency counts (Joffe and Yardley 2003). However, there is increasing recognition that content analysis makes use of features traditionally associated with quantitative as well as qualitative methods (Weber 1990). Bauer (2000, p. 132) argues:

While most classical, content analyses culminate in numerical descriptions of some features of the text corpus, considerable thought is given to the 'kinds', 'qualities' and 'distinctions' in the text before any quantification takes place. In this way, content analysis bridges statistical formalism and the qualitative analysis of the materials. In the quantity/quality divide in social research, content analysis is a hybrid technique that can mediate in this unproductive dispute over virtues and methods.

This paper adopts a critical approach. It therefore disagrees that the “"quantity”/quality divide' represents an “"unproductive” dispute over virtues and methods'. Yet it is 
This is an Accepted Manuscript of an article published by Taylor \& Francis in Journal of Gender Studies on $27^{\text {th }}$ March, 2012, available online: http://www.tandfonline.com/ 10.1080/09589236.2012.639176

important to appreciate the interpretive role of the analyst, who considers the “"kinds”, "qualities" and "distinctions" in the text' when developing categories. It is not deemed possible to capture the 'true' meaning of texts through content analysis. Thus its worth cannot be measured against conventional notions of validity, but rather the degree to which it is grounded in the text and corresponds to relevant theory as well as the aims of the research. Researchers are required to keep a clear record of their interpretations through the coding scheme (Bauer 2000). From this perspective content analysis is consistent with social constructionist understanding as it provides a means by which to systematically undertake interpretive analysis and a record against which its quality may be assessed (Joffe and Yardley 2003).

A coding scheme was developed which was partly informed by available research that explores the portrayal of men and women in television advertising. This included McArthur and Resko's (1975) influential study as well as a range of research undertaken worldwide (e.g. Livingstone and Green 1986, Arima 2003, Ganahl et al., 2003, Uray and Burnaz 2003). The categories used within these content analyses were selectively included and modified to form the current coding scheme. The aims of this study and the idiosyncrasies of its data guided this process. Such modification reflects good practice in that the coding scheme is tailored to a unique social, economic and cultural context (Furnham et al., 2000).

The coding scheme in this study was therefore developed through an iterative inductive -deductive process (see Berg 1998, Bauer 2000, Joffe and Yardley 2003). Categories were informed by data as well as by existing empirical work and theory. This process of category development facilitates comparison against existing findings and also allows exploration into novel questions (Joffe and Yardley 2003).

Content analyses often use more than a single coding unit (Berg 1998). Categories that assess features of the individual advertisement and the primary visual actors within each advertisement are common. This study likewise codes features of the individual advertisement, but specifically also examines features of the primary visual male actor within each advertisement. These are briefly described below.

\section{General advertisement attributes}

A number of advertisement attributes (i.e. date, day, day part and language) were coded but were not considered central to the current analysis. They are therefore not reported under the results.

Setting. This refers to the surroundings in which the actor(s) appeared [i.e. it included four categories and their associated sub-categories: away from home (business, outdoors, restaurant/bar, school or other/unclear); outdoors at home; indoors at home (bathroom, kitchen or other/unclear); or other/unclear]. The setting was required to remain onscreen for no less than $50 \%$ of the advertisement's duration.

Product. This refers to the product that was advertised [i.e. it included 10 categories and their associated sub-categories: vehicle and related; clothing; domestic goods (indoor or outdoor); electronic and related; food (everyday or luxury); finance (formal or informal); leisure (alcohol; book, film, music and radio; travel or sport); personal care (body/beauty care or health care); services; security; or other]. 
This is an Accepted Manuscript of an article published by Taylor \& Francis in Journal of Gender Studies on $27^{\text {th }}$ March, 2012, available online: http://www.tandfonline.com/ 10.1080/09589236.2012.639176

Primary visual male actor attributes

The primary visual male actor included all instances in which a man appeared on the screen for the longest time. His visualisation was required for no less than five seconds, during which he could appear alone or with other actors, so long as he was the primary visual focus. Animation was excluded. Likewise body parts (e.g. hands) were excluded unless clearly belonging to an identifiable actor.

Race. This is a social construct that groups individuals primarily on the basis of visible characteristics. This could be mentioned, known (as in the case of a celebrity) or determined through characteristics such as skin colour, traditional dress, accent, etc. [i.e. it included four categories and their associated sub-categories: black (Asian/Indian, black African, coloured or unclear); white; unclear; or none].

Social class. This refers to an individual's relative social ranking due to social and economic factors. This could be mentioned, known (as in the case of a celebrity) or determined through characteristics such as education/occupation, dress, accent, etc. (i.e. it included four categories: lower-/working-class; upper-/middle-class; unclear; or none).

Age. This could be mentioned, known (as in the case of a celebrity) or determined through physical features such as the face, hair, posture, clothes, etc. (i.e. it included eight categories: $0-10 ; 11-20 ; 21-30 ; 31-40 ; 41-50 ; 51-60$; 60 onwards; none).

Portrayal. This refers to the way in which the primary visual male actor was portrayed. That is to say, coders are required to judge whether the advertisement cast the actor in a favourable light (i.e. it included four categories: negative; positive; neutral; or none).

'Sexuality' norm. This norm captured the importance of men's sexuality. 'Real' men are sexuality assertive. They objectify sex. This need not involve emotion and often includes a sexual object; for example referring to women as 'cherries or chicks'. Men are expected to remain knowledgeable of as well as to initiate sexual activity. Their behavioural performance, and its positive evaluation by others, is considered crucial. Sexual behaviour extends to before, during and after the sexual act. It included two categories and their associated sub-categories [i.e. no; yes: traditional representation (e.g. a man refers to women as 'cherries' or 'chicks'), including successful or unsuccessful performance, or alternative representation (e.g. a man need not ask someone on the first date), including successful or unsuccessful performance].

'Toughness' norm. This norm captured the importance of men's toughness. 'Real' men are emotionally contained. They do not express fear or pain and remain level-headed and rational. They are physically tough and should be prepared to engage in physical violence. It included two categories and their associated sub-categories [i.e. no; yes: traditional representation (e.g. a man does not let others see he is in pain), including successful or unsuccessful performance, or alternative representation (e.g. a man discusses his emotions with others), including successful or unsuccessful performance]. 
This is an Accepted Manuscript of an article published by Taylor \& Francis in Journal of Gender Studies on $27^{\text {th }}$ March, 2012, available online: http://www.tandfonline.com/ 10.1080/09589236.2012.639176

'Independence' norm. This norm captured the importance of men’s independence. 'Real' men are assertive, self-confident, determined, self-motivated, competitive and dominating. They take initiative as well as risks. It included two categories and their associated subcategories [i.e. no; yes: traditional representation (e.g. a man should take the lead when something needs to be done), including successful or unsuccessful performance, or alternative representation (e.g. a man should be careful not to take unnecessary risks), including successful or unsuccessful performance].

'Status' norm. This norm captured the importance of men's status. 'Real' men have a successful career and lifestyle. Status is often symbolised through material means and requires the respect of others. It included two categories and their associated sub-categories [i.e. no; yes: traditional representation (e.g. a man should be successful in his work), including successful or unsuccessful performance, or alternative representation (e.g. a man's success is not measured by what he owns), including successful or unsuccessful performance].

'Responsibility' norm. This norm captures the importance of men's responsibilities. 'Real' men are dutiful and dependable toward their families, friends and society at large. They are expected to remain accountable for their actions. They should be prepared to sacrifice their own health and happiness for others. It included two categories and their associated subcategories [i.e. no; yes: traditional representation (e.g. a man should be able to provide for his family), including successful or unsuccessful performance, or alternative representation (e.g. a man should be an 'island unto himself'), including successful or unsuccessful performance].

'Homophobia' norm. This norm captures the importance of men's homophobia. 'Real' men overtly avoid, ostracise or perpetrate violence against other men or behaviour that may be considered 'gay'. It included two categories and their associated sub-categories [i.e. no; yes: traditional representation (e.g. a man who avoids 'gays'), including successful or unsuccessful performance, or alternative representation (e.g. a man who is physically intimate with other adult men), including successful or unsuccessful performance].

These six categories sought to assess latent content. They are unique, having never been applied in similar studies to date, and were informed through existing research concerning traditional norms of masculinity in SA (Luyt 2003, 2005).

\section{Coding}

A nominal measurement level was adopted in this study. This prevented the use of parametric statistics but was theoretically appropriate. Coding values were recorded on a separate coding sheet. This provided a permanent record of the coding process and aided data entry (Riffe et al., 1998).

The reliability of the coding process in content analyses remains of central importance. Inter-coder reliability exists as one of three types (Weber 1990). This assesses reproducibility or rather the extent to which a particular classification produces the same results among different coders. A number of different measures of inter-coder reliability were calculated in this study (see Appendix, Table A1).

The author acted as the first coder. A professional psychologist acted as the second. Coder training involved careful reading of and discussion surrounding the coding scheme, as well as a pilot study. The latter made use of an independent sample of approximately 20 
television advertisements. Problems encountered during coder training were resolved either through discussion or by revision of the coding scheme.

Three measures of reproducibility were calculated. These included: percentage agreement, Cohen's kappa, and Scott's pi. This was undertaken on four separate occasions. Repetition of this kind served a useful function. Instances of low reliability indicated where coding could be improved through further coder training and/or the revision of category definitions (Weber 1990, Bauer 2000, Joffe and Yardley 2003).

Fifteen percent of the coded advertisements were sampled at four roughly equal intervals during the coding process. In most cases the training and revision undertaken as a result of these calculations appear to have improved inter-coder reliability. Improvement was most marked after the first calculation. As a rule of thumb, reliability is considered very high at - 0.90; high at - 0.80; and acceptable between 0.66 and 0.79 (Bauer 2000). The final total reliability measure across all variables ranged between $\mathrm{k}^{1 / 4} 1.00$ and $\mathrm{k} 1 / 4$ 0.69. Thus inter-coder reliability in this study may be considered as ranging from very high to acceptable.

\section{Results}

The results of the content analysis are summarised in Table A2 (see Appendix). These are presented for both lower and higher order categories where appropriate.

Primary visual actor

An overall significant chi-square emerged for primary visual male actors $\left[\mathrm{x}^{2}(1\right.$, $\mathrm{n} 1 / 4$ 876) $1 / 4112.65, \mathrm{p}$ > 0.0001 ]. White males (62.67\%; $\mathrm{n} 1 \frac{1}{4} 549$ ) were more likely to appear than black males (37.33\%; n 1/4 327).

\section{Social class}

An overall significant chi square surfaced for socio-economic status $\left[\mathrm{x}^{2}(2\right.$, $n \frac{1}{4}$ 876) $1 / 4$ 42.58, $\mathrm{p}>0.0001$ ]. White males were proportionally more often represented as upper/middle social class (92.71\%; $\left.\mathrm{n} \frac{1}{4} 4509\right)$, and proportionally less frequently represented as lower/working social class (3.46\%; $n 1 / 419$ ), in comparison to black males (77.68\%; n $1 / 4254$ and 13.15\%; n $1 \frac{1}{4} 43$, respectively).

Age

An overall significant chi square emerged for age [higher order categories $x^{2}\left(3, n \frac{1}{4}\right.$ 876) $1 / 429.58, p>0.0001$ and lower order categories $x^{2}\left(6, n \frac{1}{4} 4876\right) 1 / 4144$, $\mathrm{p}>0.0001]$. White males were proportionally more often represented in the $41-60$ year-old age group (19.67\%; $n$ 1/4 108), and proportionally less frequently represented in the $11-20$ year-old age group (1.64\%; $n$ 1/4 9), in comparison to black males $(11.31 \%$; n $1 / 437$ and $15.60 \%$; n $1 / 451$, respectively). White males, however, were proportionally more often represented in the $0-10$ year-old age group (4.74\%; $\left.n \frac{1}{4} 26\right)$ in comparison to black males $\left(0.92 \% ; n^{1 / 4} 3\right)$.

Portrayal

An overall significant difference was found for portrayal $\left[x^{2}\left(2, n \frac{1}{4} 876\right) \frac{1}{4} 9.98\right.$, $p>0.01$ ]. Black males were more often represented negatively $\left(18.35 \% ; n \frac{1 / 4}{4} 60\right)$ than 
This is an Accepted Manuscript of an article published by Taylor \& Francis in Journal of Gender Studies on $27^{\text {th }}$ March, 2012, available online: http://www.tandfonline.com/ 10.1080/09589236.2012.639176

white males (14.03\%; n 1/4 77). Black (78.90\%; n 1/4 258) and white (78.69\%; n 1/4 432) males were represented positively in approximately equal proportions.

\section{Setting}

An overall significant chi-square appeared for setting [higher order categories $\mathrm{x}^{2}(3$, $n \frac{1}{4}$ 876) $1 / 4$ 73.57, $p$, 0.0001]. Chi-square analysis of lower order categories was not feasible due to cell categories less than five. Black males appeared proportionally more often in settings away from home (83.18\%; $n$ 1/4 272) than did white males (64.30\%; $n$ 1/4 353). In particular, black males appeared outdoors away from home (42.20\%; $\left.n \frac{1}{4} 138\right)$. In contrast, white males appeared proportionally more often indoors (21.49\%; $\mathrm{n} 1 / 4118)$ and outdoors (3.64\%; $n 1 / 420$ ) at home than did black males (2.45\%; $n 1 / 48$ and $0.31 \% ; n$ 1/4 1, respectively). Specifically, white males appeared in other/unclear indoor settings (9.08\%; $n$ 1/4 66). Both black and white males appeared in settings away from home more often than indoors at home.

\section{Products}

Chi-square was not possible due to cell categories less than five. Black males were more frequently associated with vehicles and related goods (16.82\%; $n$ 1/4 55) and food (31.50\%; $\mathrm{n} 1 / 4$ 103). In contrast, white males were more often associated with domestic goods (8.74\%; n 1/4 48), personal care (23.86\%; $n$ 1/4 131) and services (9.29\%; $n$ 1/4 51).

\section{'Sexuality’ norm}

An overall significant chi-square appeared for representations of sexuality [higher order categories $\mathrm{x}^{2}(1, \mathrm{n} 1 / 4$ 876) $1 / 473.57, \mathrm{p}, 0.0001$ ]. Chi-square analysis of lower order categories was not feasible due to cell categories less than five. White males were proportionally more often represented through the sexuality norm $(15.30 \%$; $n 1 / 484)$ than were black males (7.65\%; $\left.\mathrm{n} \frac{1}{4} 25\right)$. In particular, successful traditional representation appeared proportionally more frequently among white males (14.21\%; $\mathrm{n} 1 / 478$ ), as opposed to black males (7.34\%; $n$ 1/4 24). Instances of unsuccessful traditional representation and successful alternative representation appeared infrequently across each race group.

\section{‘Toughness’ norm}

An overall significant difference was found in representations of toughness [higher order categories $x^{2}\left(1, n^{1 / 4} 876\right) 1 / 47.04, p>0$. 01]. Chi-square analysis of lower order categories was not feasible due to cell categories less than five. White males were proportionally more frequently represented through the toughness norm $(28.23 \%$; $n \frac{1}{4} 155$ ) than black males (20.18\%; $\left.n \frac{1 / 4}{4} 66\right)$. Specifically, successful traditional representation appeared proportionally more frequently among white males $(21.68 \%$; $\mathrm{n} 1 / 4119)$, as opposed to black males (10.09\%; $\mathrm{n} 1 / 433)$. In contrast, unsuccessful traditional representation appeared proportionally most often among black males (10.09\%; $n \frac{1}{4}$ 33), as opposed to white males (4.92\%; $n \frac{1}{4} 27$ ). Successful alternative representation appeared infrequently and only among white males $\left(1.64 \% ; n 1 \frac{1}{4} 9\right)$.

\section{'Independence’ norm}

Chi-square results surrounding the representation of independence were mixed. A significant result emerged for lower order categories $\left[\mathrm{x}^{2}\left(3, \mathrm{n} \frac{1 / 4}{4} 876\right) \frac{1}{4} 14.73\right.$, 
This is an Accepted Manuscript of an article published by Taylor \& Francis in Journal of Gender Studies on $27^{\text {th }}$ March, 2012, available online: http://www.tandfonline.com/ 10.1080/09589236.2012.639176

$\mathrm{p}>0.01]$ but a non-significant result materialised for higher order categories $\left[\mathrm{x}^{2}(1\right.$, n $1 / 4$ 876) $1 / 4$ 1.41, NS]. Successful traditional representation appeared proportionally more frequently among white males (49.36\%; $\left.n 1 \frac{1}{4} 271\right)$, as opposed to black males $(46.18 \%$; $\mathrm{n} 1 / 4$ 151). In contrast, unsuccessful traditional representation appeared proportionally more often among black males (14.68\%; $\mathrm{n} 1 / 448)$, as opposed to white males $(9.84 \%$; $\mathrm{n} 1 / 454)$. Successful alternative representation appeared infrequently but proportionally more often among black males $\left(2.75 \% ; n 1 \frac{1}{4} 9\right)$ than white males $(0.36 \% ; n 1 / 42)$.

\section{'Status’ norm}

An overall significant difference was found in the representation of status [higher order categories $x^{2}(1, \quad n 1 / 4876) 1 / 49.41, p>0.005$ ]. Chi-square analysis of lower order categories was not feasible due to cell categories less than five. White males were proportionally more frequently represented through the status norm (30.97\%; $n$ 1/4 170) than were black males (21.41\%; $\mathrm{n} 1 / 470)$. Specifically, successful traditional representation appeared proportionally more frequently among white males $(29.14 \% ; n 1 / 4160)$, as opposed to black males (17.74\%; $n$ 1/4 58). Instances of unsuccessful traditional representation and successful alternative representation appeared infrequently across each race group.

\section{'Responsibility’ norm}

An overall non-significant chi-square surfaced for the representation of responsibility [higher order categories $x^{2}(1, n 1 / 4876) 1 / 42.19$, NS]. Chi-square analysis of lower order categories was not feasible due to cell categories less than five. Successful traditional representation appeared in similar proportions among white $(10.75 \% ; n$ (12.23\%; n 1/4 40) males. Unsuccessful traditional representation appeared infrequently and only among white males $\left(1.28 \% ; n \frac{1}{4} 7\right.$ ). Successful alternative representation appeared more often among white males (4.19\%; $n$ 1/4 23) than among black males $(0.31 \%$; $n$ 1/4 1).

\section{'Homophobia' norm}

Chi-square analysis was not possible due to cell categories less than five. No instances of successful or unsuccessful traditional representations appeared across both groups. Successful alternative representation appeared infrequently for black $(0.31 \% ; n$ well as white $\left(1.64 \% ; n \frac{1}{4} 4\right.$ 9) males.

\section{Discussion}

This study describes how masculinities and race are co-constructed in SA television advertisements. It is framed by a social constructionist perspective, and in particular, the concept of hegemonic masculinity. Findings largely support the notion that men are represented significantly differently in television advertisements depending upon their race. These differences in representation reflect an intersection between traditional gender and race relations in SA, which are marked by longstanding inequalities and serve to maintain hierarchical social relations between men in the country.

White men were significantly more likely to appear as primary visual actors than black men. Hypothesis 1 is therefore supported. This finding is especially noteworthy given that black individuals constitute by far the largest population group in SA (Statistics South Africa 2010). It also mirrors previous findings (e.g. Coltrane and Messineo 2000, Mastro and Stern 2003, Milner 2007). White men were proportionally more often represented 
This is an Accepted Manuscript of an article published by Taylor \& Francis in Journal of Gender Studies on $27^{\text {th }}$ March, 2012, available online: http://www.tandfonline.com/ 10.1080/09589236.2012.639176

as being of upper/middle social class, and proportionally less frequently represented as being of lower/working social class, in comparison to black men. As a result Hypothesis 2 is also confirmed. This arguably indicates that white men are represented as occupying positions of greater social authority vis-à-vis black men. An interpretation of this kind is strengthened by the fact that white males are proportionally more often represented as belonging to older age groups, and proportionally less frequently represented in younger age groups; apart from the $0-10$ year-old age group. The opposite is true of black males. Thus findings lend only partial support for Hypothesis 3. Existing research suggests that women are frequently represented within younger age groups as opposed to men who are represented as being older (e.g. Gilly 1988, Furnham and Bitar 1993, Furnham and Skae 1997). This is taken to suggest women's lower social authority and/or dominance as compared to men. A similar argument could be made in this case with regard to white and black men's differing age representation. The seemingly inconsistent finding that white men were proportionately more often represented in the youngest age group in comparison to black men is noteworthy, and is discussed in relation to other findings below. Whilst white and black men were represented positively in approximately the same proportions, black men were more often represented in a negative fashion as compared to white men, thus offering partial support for Hypothesis 4.

Findings concerning setting and product type do not confirm Hypotheses 5 or 6 . Black men appeared more often in settings away from home than did white men. In particular, black men frequently appeared outdoors away from home, whilst white men often appeared indoors and outdoors at home. Comparable findings appear in other empirical research (e.g. Coltrane and Messineo 2000, Mastro and Stern 2003, Milner 2007). Black men were also more frequently associated with vehicles and food, whereas white men were more often associated with domestic goods, personal care and services. It is important to note that both black and white men appeared in settings away from home more often than indoors at home, thereby generally distancing them from a setting ordinarily associated with women. Yet the proportionally greater appearance of white men in settings traditionally occupied by women, as well as their more frequent association with traditionally female-related products, appears to challenge the hypotheses. However a plausible alternative interpretation is available. Coltrane and Messineo (2000) argue that depictions of this kind contribute toward the representation of black men as being aggressive, or alternatively from the perspective of the current study, as emotionally and socially remote. They might also contribute toward the representation of white men, not as being effeminate, but as indicative of the 'new man' (Nixon 1996, Seidler 1997). The proportionally greater representation of white males as children within the $0-10$ year-old age group may also contribute toward their gentler image.

Findings provide some support for Hypothesis 7. White men were significantly more likely than black men to be associated with three out of six masculinity norms: sexuality, toughness and status. In contrast, black men were not significantly more likely than white men to be associated with any of the masculinity norms. This finding suggests that white men are gendered to a much greater extent in television advertising than black men. They therefore arguably act as a normative standard against which the 'appropriate' practice of masculinity is assessed.

White men appeared proportionally more frequently than black men as successfully representing traditional masculinity in four out of six norms: sexuality, toughness, status and independence. Black and white men appeared, by and large, equally likely to accomplish the masculinity norm of responsibility. Black men did not appear proportionally more likely than white men to accomplish any of the masculinity norms. Thus, in the majority 
This is an Accepted Manuscript of an article published by Taylor \& Francis in Journal of Gender Studies on $27^{\text {th }}$ March, 2012, available online: http://www.tandfonline.com/ 10.1080/09589236.2012.639176

of cases, white men were represented as more successful in accomplishing traditional masculinity than black men.

Black men appeared proportionally more often than white men as failing to accomplish traditional masculinity in two out of six norms: toughness and independence. White men appeared proportionally more often than black men, but nonetheless infrequently, as being unsuccessful in accomplishing the masculinity norm of responsibility. Black men were therefore more often represented as failing to accomplish traditional masculinity than white men.

Alternative representations of masculinity appeared infrequently across norms in each race group. White men appeared proportionally more frequently than black men as successfully representing alternative masculinity in two out of six norms: toughness and responsibility. Black men appeared proportionally more often than white men as successfully representing alternative masculinity in the norm of independence. Thus white men were marginally more often represented as accomplishing alternative masculinity than black men.

Instances of homophobia were not represented among either race group. Only successful alternative representation appeared. This occurred among both black and white men, but was infrequent. These results are unsurprising given the social taboo surrounding homosexuality in SA (Thurlow 2001). This may well militate against its representation in any form within media content.

A clear pattern of findings concerning alternative representations of masculinity therefore failed to emerge and, as such, Hypothesis 8 is not supported. The infrequent appearance of alternative representations of masculinity, together with mixed findings across race groups, suggests that these representations do not play a particularly important role as a counternormative standard against which the 'appropriate' practice of masculinity is assessed.

In sum, men are represented significantly differently in television advertisements depending upon their race, and these differences reflect an intersection between traditional gender and race relations. White men are represented as exemplars of hegemonic masculinity. They are: of primary focus; represented as occupying positions of greater social authority; gendered to a much greater extent in television advertising, and thereby arguably acting as a normative standard against which the 'appropriate' practice of masculinity is assessed; and are represented as more successful in accomplishing traditional masculinity. In contrast, black men are marginalised. They are more often represented: in a negative fashion; as occupying positions of social subordination; and as failing to accomplish traditional masculinity.

Yet seemingly contradictory findings emerge. White men more often appeared in settings traditionally occupied by women; they were more frequently associated with traditionally female-related products; and they were marginally more often represented as accomplishing alternative masculinity. White men may consequently represent what has been described as the 'new man'. However, as argued by others, this man should not be considered to be progressive. He remains complicit with the hegemonic project. Although he adopts some outwardly feminine practices, he does little to challenge existing relations of gender inequality, and may even embody a strategy through which these are maintained in the face of challenge (Donaldson 1993, Hanke 1998). Future research might usefully explore in greater detail the degree to which media contribute toward the representation of black men as being aggressive as well as emotionally or socially remote.

\section{Conclusion}

Masculinities and race are co-constructed in SA television advertisements. White men are frequently represented as exemplars of hegemonic masculinity whereas black men are 
This is an Accepted Manuscript of an article published by Taylor \& Francis in Journal of Gender Studies on $27^{\text {th }}$ March, 2012, available online: http://www.tandfonline.com/ 10.1080/09589236.2012.639176

often marginalised. These representations arguably mirror the inequitable distribution of economic, political and social power within SA. It has been suggested that increasing socio-economic development results in less traditional gender representation (Furnham and Spencer-Bowdage 2002). Marked political transformation has taken place in SA over the last few decades. This, however, does not appear to be reflected in men's media representation. This is not to suggest that changes in media representation have not taken place at all. Rather, it indicates the extent to which such representation still reflects an intersection between traditional gender and race relations in SA.

Gender representations inform gender practice. A reciprocal relationship between representation and practice is argued to result in the maintenance of hierarchical gender relations. In SA this involves the (re)production of hegemonic masculinity that is white and middle-class. This similarly appears in studies conducted within Western countries (Fejes 1992). It contributes toward the preservation of white men's 'internal hegemony' over black men (Demetriou 2001, p. 341).

This study provides a useful starting point for future critical analysis. It offers a broad overview of men's representation by the television media in SA. Yet the centrality model of communication content indicates that it is also essential to consider how communication content emerges as a result of antecedent conditions as well as its effect. Connell's (1987) discussion surrounding the concept of gender regimes suggests that collective social practices within media institutions may provide insight into an essential antecedent condition in the reproduction of gender representation. It is also important to consider how representation of "'hegemonic" masculinity articulates to structures and lived forms of patriarchy within everyday life' (Hanke 1998, p. 188). This is better achieved through a narrower focus. Research surrounding audience interpretation offers one example. It is increasingly encouraged by those working within the field of mass communication studies (e.g. Fejes 1992, Hanke 1998, Watkins and Emerson 2000). Fine-grained qualitative analysis offers another example.

Only higher order race categories (i.e. black and white) were considered in the analysis. This study focussed on the intersection between traditional overarching masculinity and race relations in SA. These have historically been characterised, as noted above, by the dominance of white men and the subordination of black men. As such, possible differences in the representation of black men (i.e. between Asian/Indian, black African and coloured) were of less immediate concern. Future work might usefully hypothesise and explore these differences.

Existing coding schemes, including the current one, arguably develop a greater number of categories to describe the primary visual actor (e.g. age and portrayal) than those describing the general advertisement (e.g. setting and product). This might be addressed in future studies. For example, a much wider set of categories might be developed in order to describe advertisement setting or context. Results indicating that white males appeared proportionally more often at home than did black males limit the interpretation. This tells us little of the activities they were engaged in. Were they perpetrating domestic violence, preparing evening meals or watching team sports on television? Our conclusions might be rather different depending upon such information. Although undoubtedly useful, such a coding scheme development should be undertaken with caution. It should ensure that the coding scheme is tailored to the unique research context, as well as allow for exploration into novel questions, but should remain faithful to core categories applied in existing coding schemes so as to facilitate comparison of findings over time.

Finally it is important to underline that this study has explored the representation of gender at a national or regional level. This contributes toward the description of what Connell and Messerschmidt (2005, p. 849) have called a 'geography of masculinities'. 
This is an Accepted Manuscript of an article published by Taylor \& Francis in Journal of Gender Studies on $27^{\text {th }}$ March, 2012, available online: http://www.tandfonline.com/ 10.1080/09589236.2012.639176

However, few studies consider the extent to which global masculinity shapes those at a regional and local level. Salo's (2003) study provides one of the few examples. The author describes the influence of global culture on post-Apartheid shifts in masculine and feminine identities within the coloured township of Manenberg on the Cape Flats. More work should be undertaken in this area.

\section{Acknowledgements}

Research funds were made available through the Commonwealth Commission and Universities UK. Special thanks go to Hayley Nichols and Jenny Luyt for their research assistance.

Note

1. The use of social categories in research, including those of race and gender, has stimulated much debate. Concern primarily surrounds the extent to which research contributes toward the reification of social categories and thereby helps to maintain axes of inequality in society. This study makes use of social categories. However, these are understood as social constructs and not essential to individuals. Their use is justified though their contemporary meaningfulness. Category descriptors reflect their current construction in South African society. For example, in the case of race, these include Asian, black African, coloured and white.

\section{Notes on contributor}

Russell Luyt is a senior lecturer in the Department of Psychology at the University of Winchester. He is particularly interested in identity processes as well as debates concerning research philosophy and qualitative methodology. His work is grounded within a critical approach and has, to date, focused primarily on the social psychology of gender. This has included, for example: the critique of traditional masculinity, femininity and gender measurement; media representations; masculinities and aggression; as well as the intersection of gender and other social categories. He is currently extending these lines of research and developing his interest in radicalisation among marginalised communities from a gender perspective.

\section{References}

Arima, A.N., 2003. Gender stereotypes in Japanese television advertisements. Sex roles, 49 (1/2), $81-90$.

Bandura, A., 2001. Social cognitive theory of mass communication. Media psychology, 3 (3), 265-299.

Bauer, M.W., 2000. Classical content analysis: a review. In: M.W. Bauer and G. Gaskell, eds.

Qualitative researching: with text image and sound. London: Sage Publications, 131-151. Berg, B.L., 1998. Qualitative research methods for the social sciences. Boston, MA: Allyn and Bacon.

Bird, S.R., 1996. Welcome to the men's club: homosociality and the maintenance of hegemonic masculinity. Gender \& society, 10 (2), 120-132.

Bohan, J.S., 1993. Regarding gender: essentialism, constructionism, and feminist psychology. Psychology of women quarterly, 17 (1), 5-21.

Boni, F., 2002. Framing media masculinities: men's lifestyle magazines and the biopolitics of the male body. European journal of communication, 17 (4), 465-478.

Brannon, L., 1999. Gender: psychological perspectives. Boston, MA: Allyn and Bacon.

Burns, C., 1998. 'A man is a clumsy thing who does not know how to handle a sick person': aspects of the history of masculinity and race in the shaping of male nursing in South Africa, 19001950. Journal of Southern African studies, 24 (4), 695-717.

Carrigan, T., Connell, B. and Lee, J., 1985. Toward a new sociology of masculinity. Theory \& society, 14 (5), 551-604.

Clarke, J.N., 1999. Prostate cancer's hegemonic masculinity in select print mass media depictions; 1974-1995. Health communication, 11 (1), 59-74. 
This is an Accepted Manuscript of an article published by Taylor \& Francis in Journal of Gender Studies on $27^{\text {th }}$ March, 2012, available online: http://www.tandfonline.com/ 10.1080/09589236.2012.639176

Coltrane, S. and Messineo, M., 2000. The perpetuation of subtle prejudice: race and gender imagery in television advertising. Sex roles, 42 (5/6), 363-389.

Conekin, B., 2000. Fashioning the playboy: messages of style and masculinity in pages of Playboy Magazine, 1953-1963. Fashion theory, 4 (4), 447-466.

Connell, R.W., 1987. Gender and power: society, the person and sexual politics. Cambridge: Polity Press.

Connell, R.W., 1993. The big picture: masculinities in recent world history. Theory \& society, 22 (5), 597-623.

Connell, R.W., 1995. Masculinities. Cambridge: Polity Press.

Connell, R.W., 2000. The men and the boys. Cambridge: Polity Press.

Connell, R.W., 2002. On hegemonic masculinity and violence: response to Jefferson and Hall. Theoretical criminology, 6 (1), 89-99.

Connell, R.W. and Messerschmidt, J.W., 2005. Hegemonic masculinity: rethinking the concept. Gender \& society, 19 (6), 829-859.

Craig, R.S., 1992a. Considering men and the media. In: R.S. Craig, ed. Men, masculinity and the media. Newbury Park, CA: Sage Publications, 1-7.

Craig, R.S., 1992b. The effect of television day part on gender portrayals in television commercials: a content analysis. Sex roles, 26 (5/6), 197-211.

Demetriou, D.Z., 2001. Connell’s concept of hegemonic masculinity: a critique. Theory \& society, 30 (3), 337-361.

Donaldson, M., 1993. What is hegemonic masculinity? Theory \& society, 22 (5), 643-657.

Feinstein, C.H., 2005. An economic history of South Africa. Cambridge: Cambridge University Press.

Fejes, F.J., 1992. Masculinity as fact: a review of empirical mass communication research on masculinity. In: R.S. Craig, ed. Men, masculinity and the media. Newbury Park, CA: Sage Publications, 9-22.

Furnham, A. and Bitar, N., 1993. The stereotyped portrayal of men and women in British television advertisements. Sex roles, 29 (3/4), 297-310.

Furnham, A., Mak, T. and Tanidjojo, L., 2000. An Asian perspective on the portrayal of men and women in television advertisements: studies from Hong Kong and Indonesian television. Journal of applied social psychology, 30 (11), 2341-2364.

Furnham, A. and Skae, E., 1997. Portrayals of men and women in British television advertisements. European psychologist, 2 (1), 14-51.

Furnham, A. and Spencer-Bowdage, S., 2002. Sex role stereotyping in television advertisements: a content analysis of advertisements from South Africa and Great Britain. Communications, 27 (4), 457-483.

Ganahl, D.J., Prinsen, T.J. and Netzley, S.B., 2003. A content analysis of prime time commercials: a contextual framework of gender representation. Sex roles, 49 (9/10), 545-551.

Gerbner, G. and Gross, L., 1976. Living with television: the violence profile. Journal of communication, 26 (2), 172-199.

Gilly, M.C., 1988. Gender roles in advertising: a comparison of television advertisements in Australia, Mexico, and the United States. Journal of marketing, 52 (2), 75-85.

Hall, S., 2002. Daubing the drudges of fury: men, violence and the piety of the 'hegemonic masculinity’ thesis. Theoretical criminology, 6 (1), 35-61.

Hanke, R., 1992. Redesigning men: hegemonic masculinity in transition. In: R.S. Craig, ed. Men, masculinity and the media. Newbury Park, CA: Sage Publications, 185-198.

Hanke, R., 1998. Theorizing masculinity within/in the media. Communication theory, 8 (2), 183-203.

Hodgetts, D. and Chamberlain, K., 2002. 'The problem with men': working-class men making sense of men's health on television. Journal of health psychology, 7 (3), 269-283.

Jefferson, T., 2002. Subordinating hegemonic masculinity. Theoretical criminology, 6 (1), 63-88.

Joffe, H. and Yardley, L., 2003. Content and thematic analysis. In: D.F. Marks and L. Yardley, eds. Research methods for clinical and health psychology. London: Sage Publications, 56-88.

Kalichman, S.C., et al., 2005. Gender attitudes, sexual violence, and HIV/AIDS risks among men and women in Cape Town, South Africa. Journal of sex research, 42 (4), 299-305.

Livingstone, S. and Green, G., 1986. Television advertisements and the portrayal of gender. British journal of social psychology, 25 (2), 149-154.

Luyt, R., 2003. Rhetorical representations of masculinities in South Africa: moving towards a material-discursive understanding of men. Journal of community and applied social psychology, 13 (1), 46-69. 
This is an Accepted Manuscript of an article published by Taylor \& Francis in Journal of Gender Studies on $27^{\text {th }}$ March, 2012, available online: http://www.tandfonline.com/ 10.1080/09589236.2012.639176

Luyt, R., 2005. The Male Attitude Norms Inventory-II: a measure of masculinity ideology in South Africa. Men \& masculinities, 8 (2), 208-229.

Luyt, R. and Foster, D., 2001. Hegemonic masculine conceptualisation in gang culture. South African journal of psychology, 31 (3), 1-11.

Mastro, D.E. and Stern, S.R., 2003. Representations of race in television commercials: a content analysis of prime-time advertising. Journal of broadcasting and electronic media, 47 (4), 638-647.

McArthur, L.Z. and Resko, B.G., 1975. The portrayal of men and women in American television commercials. Journal of social psychology, 97 (2), 209-220.

McCombs, M.E. and Shaw, D.L., 1972. The agenda-setting function of mass media. Public opinion quarterly, 36 (2), 176-187.

McKay, J. and Middlemiss, I., 1995. 'Mate against mate, state against state': a case study of media

constructions of hegemonic masculinity in Australian sport. Masculinities, 3 (3), 28-45. Milner, L.M., 2005. Sex-role portrayals in African television advertising. Journal of international consumer marketing, 17 (2/3), 73-91.

Milner, L.M., 2007. Race portrayals in Ghana, Kenya and South Africa television advertisements. Journal of African business, 8 (2), 41-59.

Moon, Y.S. and Chan, K., 2002. Gender portrayal in Hong Kong and Korean children's TV commercials: a cross-cultural comparison. Asian journal of communication, 12 (2), 100-119.

Neuendorf, K.A., 2002. The content analysis guidebook. Thousand Oaks, CA: Sage Publications.

Nixon, S., 1996. Hard looks: masculinities, spectatorship and contemporary consumption. London: University College London Press.

Reddy, S. and Dunne, M., 2007. Risking it: young heterosexual femininities in South African context of HIV/AIDS. Sexualities, 10 (2), 159-172.

Riffe, D., Lacy, S. and Fico, F.G., 1998. Analyzing media messages: using quantitative content analysis in research. Mahwah, NJ: Lawrence Erlbaum Associates.

Salo, E., 2003. Negotiating gender and personhood in the new South Africa: adolescent women and gangsters in Manenberg township on the Cape Flats. European journal of cultural studies, 6 (3), 345-365.

Seidler, V.J., 1997. Man enough: embodying masculinities. London: Sage Publications.

Statistics South Africa (SSA), 2003. Census 2001: census in brief. Pretoria: Statistics South Africa.

Statistics South Africa (SSA), 2007a. Provincial profile 2004: Limpopo. Pretoria: Statistics South Africa.

Statistics South Africa (SSA), 2007b. Community survey, 2007: revised version. Pretoria: Statistics South Africa.

Statistics South Africa (SSA), 2010. Mid-year population estimates. Pretoria: Statistics South Africa.

Strate, L., 1992. Beer commercials: a manual on masculinity. In: R.S. Craig, ed. Men, masculinity and the media. Newbury Park, CA: Sage Publications, 78-92.

Thurlow, C., 2001. Naming the 'outsider within': homophobic pejoratives and the verbal abuse of lesbian, gay and bisexual high-school pupils. Journal of adolescence, 24 (1), 25-38.

Trujillo, N., 1991. Hegemonic masculinity on the mound: media representations of Nolan Ryan and American sports culture. Critical studies in media communication, 8 (3), 290-308.

United Nations Development Programme (UNDP), 2009. Human development report 2009. Basingstoke: Palgrave Macmillan.

Uray, N. and Burnaz, S., 2003. An analysis of the portrayal of gender roles in Turkish television advertisements. Sex roles, 48 (1/2), 77-87.

Watkins, S.C. and Emerson, R.A., 2000. Feminist media criticism and feminist media practices. The annals of the American Academy, 571 (1), 151-166.

Weber, R.P., 1990. Basic content analysis. Newbury Park, CA: Sage Publications.

West, C. and Zimmerman, D.H., 1991. Doing gender. In: J. Lorber and S.A. Farrell eds. The social construction of gender. Newbury Park, CA: Sage Publications, 13-37.

Wetherell, M. and Edley, N., 1999. Negotiating hegemonic masculinity: imaginary positions and psycho-discursive practices. Feminism \& psychology, 9 (3), 335-356.

Wilkinson, S., 2001. Theoretical perspectives on women and gender. In: R.K. Unger, ed. Handbook of the psychology of women and gender. Hoboken, NJ: John Wiley and Sons, 17-28.

Wilkinson, W.W., 2004. Authoritarian hegemony, dimensions of masculinity, and male antigay attitudes. Psychology of men \& masculinity, 5 (2), 121-131. 


\section{Appendix}

Table A1. Measures of inter-coder agreement.

\begin{tabular}{|c|c|c|c|c|c|}
\hline $\begin{array}{l}\text { Variable } \\
\text { number }\end{array}$ & Category & $\begin{array}{l}\text { Inter-rater } \\
\text { agreement } \\
\text { Measure } 1 \\
*(\mathrm{n} 1 / 476) \\
* *(\mathrm{n} 1 / 49)\end{array}$ & 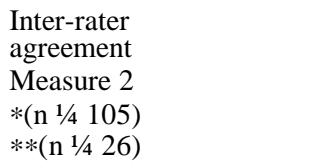 & $\begin{array}{l}\text { Inter-rater } \\
\text { agreement } \\
\text { Measure } 3 \\
*(n \text { 1/4 143) } \\
* *(n \text { 1 1 4 48) }\end{array}$ & $\begin{array}{l}\text { Inter-rater } \\
\text { agreement } \\
\text { Final measure } \\
*\left(\mathrm{n} 1 / 4_{4} 432\right) \\
* *\left(\mathrm{n} 1 / 4^{1 / 27}\right)\end{array}$ \\
\hline v1.* & $\begin{array}{l}\text { Gender of primary } \\
\text { visual actor }\end{array}$ & $\begin{array}{l}\text { Pct. agreement } 1 / 478.9 \% \\
\text { Cohen's kappa } 1 / 40.652 \\
\text { Scott's pi } 1 / 40.642\end{array}$ & $\begin{array}{l}\text { Pct. agreement } 1 / 494.3 \% \\
\text { Cohen's kappa } 1 / 40.909 \\
\text { Scott's pi } 1 / 40.909\end{array}$ & $\begin{array}{l}\text { Pct. agreement } 1 / 492.3 \% \\
\text { Cohen’s kappa } 1 / 40.883 \\
\text { Scott's pi } 1 / 40.883\end{array}$ & $\begin{array}{l}\text { Pct. agreement } 1 \frac{1}{4} 90.7 \% \\
\text { Cohen's kappa } 1 / 40.860 \\
\text { Scott's pi } 1 / 40.860\end{array}$ \\
\hline v2.* & $\begin{array}{l}\text { Race of primary visual actor } \\
\text { (lower order categories) }\end{array}$ & $\begin{array}{l}\text { Pct. agreement } 1 / 478.9 \% \\
\text { Cohen's kappa } 1 / 40.666 \\
\text { Scott's pi } 1 / 40.657\end{array}$ & $\begin{array}{l}\text { Pct. agreement } 1 / 496.2 \% \\
\text { Cohen's kappa } 1 / 40.937 \\
\text { Scott's pi } 1 / 40.937\end{array}$ & $\begin{array}{l}\text { Pct. agreement } 1 / 491.6 \% \\
\text { Cohen's kappa } 1 / 40.862 \\
\text { Scott's pi } 1 / 40.862\end{array}$ & $\begin{array}{l}\text { Pct. agreement } 1 / 491.2 \% \\
\text { Cohen’s kappa } 1 / 40.865 \\
\text { Scott's pi } 1 / 40.865\end{array}$ \\
\hline v2.* & $\begin{array}{l}\text { Race of primary visual actor } \\
\text { (higher order categories) }\end{array}$ & $\begin{array}{l}\text { Pct. agreement } 1 \frac{1}{4} 78.9 \% \\
\text { Cohen's kappa } 1 / 40.655 \\
\text { Scott's pi } 1 / 40.644\end{array}$ & $\begin{array}{l}\text { Pct. agreement } 1 / 496.2 \% \\
\text { Cohen's kappa } 1 / 40.937 \\
\text { Scott's pi } 1 / 40.937\end{array}$ & $\begin{array}{l}\text { Pct. agreement } 1 / 492.3 \% \\
\text { Cohen's kappa } 1 / 40.872 \\
\text { Scott's pi } 1 / 40.872\end{array}$ & $\begin{array}{l}\text { Pct. agreement } 1 \frac{1}{4} 91.9 \% \\
\text { Cohen’s kappa } 1 / 40.873 \\
\text { Scott's pi } 1 / 40.873\end{array}$ \\
\hline v3.* & $\begin{array}{l}\text { Social class of primary } \\
\text { visual actor }\end{array}$ & $\begin{array}{l}\text { Pct. agreement } 1 \frac{1}{4} 77.6 \% \\
\text { Cohen's kappa } 1 / 40.601 \\
\text { Scott's pi } 1 / 40.587\end{array}$ & $\begin{array}{l}\text { Pct. agreement } 1 / 493.3 \% \\
\text { Cohen's kappa } 1 / 40.881 \\
\text { Scott's pi } 1 / 40.880\end{array}$ & $\begin{array}{l}\text { Pct. agreement } 1 / 491.6 \% \\
\text { Cohen's kappa } 1 / 40.840 \\
\text { Scott's pi } 1 / 40.839\end{array}$ & $\begin{array}{l}\text { Pct. agreement } 1 \frac{1}{4} 88.7 \% \\
\text { Cohen's kappa } 1 / 40.798 \\
\text { Scott's pi } 1 / 40.798\end{array}$ \\
\hline $\mathrm{v} 4 . *$ & $\begin{array}{l}\text { Age of primary visual } \\
\text { actor (lower order categories) }\end{array}$ & $\begin{array}{l}\text { Pct. agreement } 1 / 473.7 \% \\
\text { Cohen's kappa } 1 / 40.573 \\
\text { Scott's pi } 1 / 40.562\end{array}$ & $\begin{array}{l}\text { Pct. agreement 1/4 } 86.7 \% \\
\text { Cohen's kappa } 1 / 40.794 \\
\text { Scott's pi } 1 \frac{1}{4} 0.794\end{array}$ & $\begin{array}{l}\text { Pct. agreement } 1 / 481.8 \% \\
\text { Cohen's kappa } 1 / 40.739 \\
\text { Scott's pi } 1 / 40.738\end{array}$ & $\begin{array}{l}\text { Pct. agreement } 1 / 482.9 \% \\
\text { Cohen's kappa } 1 / 40.751 \\
\text { Scott's pi } 1 / 40.751\end{array}$ \\
\hline $\mathrm{v} 4 . *$ & $\begin{array}{l}\text { Age of primary visual actor } \\
\text { (higher order categories) }\end{array}$ & $\begin{array}{l}\text { Pct. agreement } 1 \frac{1}{4} 76.3 \% \\
\text { Cohen's kappa } 1 / 40.594 \\
\text { Scott's pi } 1 / 40.583\end{array}$ & $\begin{array}{l}\text { Pct. agreement } 1 / 492.4 \% \\
\text { Cohen's kappa } 1 / 40.872 \\
\text { Scott's pi } 1 / 40.872\end{array}$ & $\begin{array}{l}\text { Pct. agreement } 1 / 486.7 \% \\
\text { Cohen's kappa } 1 / 40.778 \\
\text { Scott's pi } 1 \frac{1}{4} 0.777\end{array}$ & $\begin{array}{l}\text { Pct. agreement } 1 / 487.3 \% \\
\text { Cohen's kappa } 1 / 40.788 \\
\text { Scott's pi } 1 / 40.788\end{array}$ \\
\hline v5.* & Portrayal of primary visual actor & $\begin{array}{l}\text { Pct. agreement } 1 / 475.0 \% \\
\text { Cohen's kappa } 1 / 40.565 \\
\text { Scott's pi } 1 / 40.546\end{array}$ & $\begin{array}{l}\text { Pct. agreement } 1 / 492.4 \% \\
\text { Cohen's kappa } 1 / 40.859 \\
\text { Scott's pi } 1 / 40.859\end{array}$ & $\begin{array}{l}\text { Pct. agreement } 1 / 491.6 \% \\
\text { Cohen's kappa } 1 / 40.848 \\
\text { Scott's pi } 1 / 40.848\end{array}$ & $\begin{array}{l}\text { Pct. agreement } 1 / 489.6 \% \\
\text { Cohen's kappa } 1 / 40.820 \\
\text { Scott's pi } 1 / 40.820\end{array}$ \\
\hline v6.* & Setting (lower order categories) & $\begin{array}{l}\text { Pct. agreement } 1 / 480.3 \% \\
\text { Cohen's kappa } 1 / 40.713 \\
\text { Scott's pi } 1 / 40.713\end{array}$ & $\begin{array}{l}\text { Pct. agreement } 1 / 484.8 \% \\
\text { Cohen's kappa } 1 \frac{1}{4} 0.787 \\
\text { Scott's pi } 1 / 40.786\end{array}$ & $\begin{array}{l}\text { Pct. agreement } 1 / 486.0 \% \\
\text { Cohen's kappa } 1 \frac{1}{4} 0.814 \\
\text { Scott's pi } 1 / 40.814\end{array}$ & $\begin{array}{l}\text { Pct. agreement } 1 / 484.7 \% \\
\text { Cohen's kappa } 1 / 40.799 \\
\text { Scott's pi } 1 / 40.799\end{array}$ \\
\hline
\end{tabular}


Table A1 - continued

\begin{tabular}{|c|c|c|c|c|c|}
\hline $\begin{array}{l}\text { Variable } \\
\text { number }\end{array}$ & Category & $\begin{array}{l}\text { Inter-rater } \\
\text { agreement } \\
\text { Measure } 1 \\
*(\mathrm{n} 1 / 476) \\
* *\left(\mathrm{n} 1 / 4^{1 / 4}\right)\end{array}$ & $\begin{array}{l}\text { Inter-rater } \\
\text { agreement } \\
\text { Measure } 2 \\
*(n \text { 1/4 105) } \\
* *(n \text { 1/4 26) }\end{array}$ & $\begin{array}{l}\text { Inter-rater } \\
\text { agreement } \\
\text { Measure } 3 \\
*(\mathrm{n} 1 / 4143) \\
* *(n \text { 1 1 4 48) }\end{array}$ & $\begin{array}{l}\text { Inter-rater } \\
\text { agreement } \\
\text { Final measure } \\
*(\mathrm{n} 1 / 4432) \\
* *\left(\mathrm{n} 1 / 4^{1 / 427}\right)\end{array}$ \\
\hline v6.* & Setting (higher order categories) & $\begin{array}{l}\text { Pct. agreement } 1 \frac{1}{4} 88.2 \% \\
\text { Cohen’s kappa } 1 / 40.796 \\
\text { Scott's pi } 1 \frac{1}{4} 0.796\end{array}$ & $\begin{array}{l}\text { Pct. agreement } 1 / 4 \text { 88.6\% } \\
\text { Cohen's kappa } 1 / 40.816 \\
\text { Scott's pi } 1 / 40.815\end{array}$ & $\begin{array}{l}\text { Pct. agreement } 1 / 490.9 \% \\
\text { Cohen's kappa } 1 / 40.857 \\
\text { Scott's pi } 1 / 40.857\end{array}$ & $\begin{array}{l}\text { Pct. agreement } 1 / 489.4 \% \\
\text { Cohen's kappa } 1 / 40.833 \\
\text { Scott's pi } 1 / 40.833\end{array}$ \\
\hline v7.* & Products (lower order categories) & $\begin{array}{l}\text { Pct. agreement } 1 \frac{1}{4} 92.1 \% \\
\text { Cohen's kappa } 1 / 40.908 \\
\text { Scott's pi } 1 \frac{1}{4} 0.908\end{array}$ & $\begin{array}{l}\text { Pct. agreement } 1 / 496.2 \% \\
\text { Cohen's kappa } 1 / 40.957 \\
\text { Scott's pi } 1 / 40.957\end{array}$ & $\begin{array}{l}\text { Pct. agreement } 1 / 494.4 \% \\
\text { Cohen's kappa } 1 / 40.938 \\
\text { Scott's pi } 1 / 40.938\end{array}$ & $\begin{array}{l}\text { Pct. agreement } 1 / 493.3 \% \\
\text { Cohen's kappa } 1 / 40.926 \\
\text { Scott's pi } 1 / 40.926\end{array}$ \\
\hline v7.* & Products (higher order categories) & $\begin{array}{l}\text { Pct. agreement } 1 \frac{1}{4} 93.4 \% \\
\text { Cohen's kappa } 1 / 40.918 \\
\text { Scott's pi } 1 \frac{1}{4} 0.918\end{array}$ & $\begin{array}{l}\text { Pct. agreement } 1 / 497.1 \% \\
\text { Cohen's kappa } 1 / 40.966 \\
\text { Scott's pi } 1 / 40.966\end{array}$ & $\begin{array}{l}\text { Pct. agreement } 1 / 495.8 \% \\
\text { Cohen's kappa } 1 / 40.951 \\
\text { Scott's pi } 1 \frac{1}{4} 0.951\end{array}$ & $\begin{array}{l}\text { Pct. agreement } 1 / 494.4 \% \\
\text { Cohen's kappa } 1 / 40.936 \\
\text { Scott's pi } 1 / 40.936\end{array}$ \\
\hline v8.** & $\begin{array}{l}\text { 'Sexuality’ norm displayed by } \\
\text { primary visual male actor } \\
\text { (lower order categories) }\end{array}$ & $\begin{array}{l}\text { Pct. agreement } 1 / 4100 \% \\
\text { Cohen's kappa } 1 / 41.000 \\
\text { Scott's pi } 1 / 41.000\end{array}$ & $\begin{array}{l}\text { Pct. agreement } 1 / 4 \text { 92.3\% } \\
\text { Cohen's kappa } 1 / 40.775 \\
\text { Scott's pi } 1 / 40.774\end{array}$ & $\begin{array}{l}\text { Pct. agreement } 1 / 491.7 \% \\
\text { Cohen's kappa } 1 / 40.567 \\
\text { Scott's pi } 1 / 40.565\end{array}$ & $\begin{array}{l}\text { Pct. agreement } 1 / 496.9 \% \\
\text { Cohen's kappa } 1 / 40.842 \\
\text { Scott's pi } 1 / 40.842\end{array}$ \\
\hline $\mathrm{v} 8 . * *$ & $\begin{array}{l}\text { 'Sexuality’ norm displayed by } \\
\text { primary visual male actor } \\
\text { (higher order categories) }\end{array}$ & $\begin{array}{l}\text { Pct. agreement } 1 / 4100 \% \\
\text { Cohen's kappa } 1 / 41.000 \\
\text { Scott's pi } 1 / 41.000\end{array}$ & $\begin{array}{l}\text { Pct. agreement } 1 / 496.2 \% \\
\text { Cohen's kappa } 1 / 40.885 \\
\text { Scott's pi } 1 / 40.885\end{array}$ & $\begin{array}{l}\text { Pct. agreement } 1 / 491.7 \% \\
\text { Cohen's kappa } 1 / 40.556 \\
\text { Scott's pi } 1 / 40.553\end{array}$ & $\begin{array}{l}\text { Pct. agreement } 1 / 496.9 \% \\
\text { Cohen's kappa } 1 / 40.839 \\
\text { Scott's pi } 1 / 40.839\end{array}$ \\
\hline $\mathrm{v} 9 . * *$ & $\begin{array}{l}\text { 'Toughness’ norm displayed by } \\
\text { primary visual male actor } \\
\text { (lower order categories) }\end{array}$ & $\begin{array}{l}\text { Pct. agreement } 1 / 466.7 \% \\
\text { Cohen's kappa } 1 / 40.491 \\
\text { Scott's pi } 1 / 40.465\end{array}$ & $\begin{array}{l}\text { Pct. agreement } 1 / 484.6 \% \\
\text { Cohen's kappa } 1 / 40.532 \\
\text { Scott’s pi } 1 / 40.528\end{array}$ & $\begin{array}{l}\text { Pct. agreement } 1 / 495.8 \% \\
\text { Cohen's kappa } 1 / 40.922 \\
\text { Scott's pi } 1 / 40.922\end{array}$ & $\begin{array}{l}\text { Pct. agreement } 1 / 496.1 \% \\
\text { Cohen's kappa } 1 / 40.907 \\
\text { Scott's pi } 1 / 40.907\end{array}$ \\
\hline v9.** & $\begin{array}{l}\text { 'Toughness' norm displayed by } \\
\text { primary visual male actor } \\
\text { (higher order categories) }\end{array}$ & $\begin{array}{l}\text { Pct. agreement } 1 \frac{1}{4} 77.8 \% \\
\text { Cohen’s kappa } 1 / 40.526 \\
\text { Scott's pi } 1 / 40.500\end{array}$ & $\begin{array}{l}\text { Pct. agreement } 1 / 484.6 \% \\
\text { Cohen’s kappa 1/4 } 0.509 \\
\text { Scott's pi } 1 / 40.505\end{array}$ & $\begin{array}{l}\text { Pct. agreement } 1 / 4100 \% \\
\text { Cohen’s kappa } 1 / 41.000 \\
\text { Scott's pi } 1 / 41.000\end{array}$ & $\begin{array}{l}\text { Pct. agreement } 1 / 496.9 \% \\
\text { Cohen's kappa } 1 / 40.920 \\
\text { Scott's pi } 1 / 40.920\end{array}$ \\
\hline $\mathrm{v} 10 . * *$ & $\begin{array}{l}\text { 'Independence' norm displayed by } \\
\text { primary visual male actor } \\
\text { (lower order categories) }\end{array}$ & $\begin{array}{l}\text { Pct. agreement } 1 / 477.8 \% \\
\text { Cohen’s kappa } 1 / 40.526 \\
\text { Scott’s pi } 1 / 40.500\end{array}$ & $\begin{array}{l}\text { Pct. agreement } 1 / 480.8 \% \\
\text { Cohen's kappa } 1 / 40.607 \\
\text { Scott's pi } 1 / 40.607\end{array}$ & $\begin{array}{l}\text { Pct. agreement } 1 / 489.6 \% \\
\text { Cohen's kappa } 1 / 40.819 \\
\text { Scott's pi } 1 / 40.819\end{array}$ & $\begin{array}{l}\text { Pct. agreement } 1 / 485.0 \% \\
\text { Cohen's kappa } 1 / 40.755 \\
\text { Scott's pi } 1 / 40.754\end{array}$ \\
\hline
\end{tabular}


Table A1 - continued

\begin{tabular}{|c|c|c|c|c|c|}
\hline & & $\begin{array}{l}\text { Inter-rater } \\
\text { agreement }\end{array}$ & $\begin{array}{l}\text { Inter-rater } \\
\text { agreement }\end{array}$ & $\begin{array}{l}\text { Inter-rater } \\
\text { agreement }\end{array}$ & $\begin{array}{l}\text { Inter-rater } \\
\text { agreement }\end{array}$ \\
\hline $\begin{array}{l}\text { Variable } \\
\text { number }\end{array}$ & Category & $\begin{array}{l}\text { Measure } 1 \\
*\left(\mathrm{n} 1 / 4^{1 / 46)}\right. \\
* *\left(\mathrm{n}^{1 / 4} 9\right)\end{array}$ & $\begin{array}{l}\text { Measure } 2 \\
*\left(\mathrm{n}^{1 / 4} 105\right) \\
* *\left(\mathrm{n}^{1 / 4} 26\right)\end{array}$ & $\begin{array}{l}\text { Measure } 3 \\
*(\mathrm{n} 1 / 4143) \\
* *(\text { n } 1 / 448)\end{array}$ & $\begin{array}{l}\text { Final measure } \\
*\left(n{ }^{1 / 4} 432\right) \\
* *\left(n \frac{1}{1} 127\right)\end{array}$ \\
\hline $\mathrm{v} 10 . * *$ & $\begin{array}{l}\text { 'Independence' norm displayed by } \\
\text { primary visual male actor } \\
\text { (higher order categories) }\end{array}$ & $\begin{array}{l}\text { Pct. agreement } 1 \frac{1}{4} 77.8 \% \\
\text { Cohen’s kappa } 1 / 40.526 \\
\text { Scott's pi } 1 / 40.500\end{array}$ & $\begin{array}{l}\text { Pct. agreement } 1 / 480.8 \% \\
\text { Cohen's kappa } 1 / 40.586 \\
\text { Scott's pi } 1 / 40.585\end{array}$ & $\begin{array}{l}\text { Pct. agreement } 1 / 493.8 \% \\
\text { Cohen's kappa } 1 / 40.829 \\
\text { Scott's pi } 1 / 40.828\end{array}$ & $\begin{array}{l}\text { Pct. agreement } 1 / 485.0 \% \\
\text { Cohen’s kappa } 1 / 40.690 \\
\text { Scott's pi } 1 / 40.690\end{array}$ \\
\hline v11.** & $\begin{array}{l}\text { 'Status' norm displayed by } \\
\text { primary visual male actor } \\
\text { (lower order categories) }\end{array}$ & $\begin{array}{l}\text { Pct. agreement } 1 / 477.8 \% \\
\text { Cohen’s kappa } 1 / 40.400 \\
\text { Scott's pi } 1 / 40.357\end{array}$ & $\begin{array}{l}\text { Pct. agreement } 1 / 488.5 \% \\
\text { Cohen's kappa } 1 / 40.655 \\
\text { Scott's pi } 1 / 40.654\end{array}$ & $\begin{array}{l}\text { Pct. agreement } 1 / 487.5 \% \\
\text { Cohen's kappa } 1 / 40.745 \\
\text { Scott's pi } 1 / 40.745\end{array}$ & $\begin{array}{l}\text { Pct. agreement } 1 / 492.9 \% \\
\text { Cohen’s kappa } 1 / 40.818 \\
\text { Scott's pi } 1 \frac{1}{4} 0.818\end{array}$ \\
\hline v11.** & $\begin{array}{l}\text { 'Status' norm displayed by } \\
\text { primary visual male actor } \\
\text { (higher order categories) }\end{array}$ & $\begin{array}{l}\text { Pct. agreement } 1 / 477.8 \% \\
\text { Cohen's kappa } 1 / 40.400 \\
\text { Scott's pi } 1 / 40.357\end{array}$ & $\begin{array}{l}\text { Pct. agreement } 1 / 488.5 \% \\
\text { Cohen's kappa } 1 / 40.655 \\
\text { Scott's pi } 1 / 40.654\end{array}$ & $\begin{array}{l}\text { Pct. agreement } 1 / 487.5 \% \\
\text { Cohen's kappa } 1 / 40.734 \\
\text { Scott's pi } 1 / 40.733\end{array}$ & $\begin{array}{l}\text { Pct. agreement } 1 / 492.9 \% \\
\text { Cohen's kappa } 1 / 40.814 \\
\text { Scott's pi } 1 \frac{1}{4} 0.814\end{array}$ \\
\hline v12.** & 'Responsibility’ norm displayed & $\begin{array}{l}\text { Pct. agreement } 1 \frac{1}{4} 88.9 \% \\
\text { Cohen's kappa } 1 / 40.609 \\
\text { Scott's pi } 1 / 40.600\end{array}$ & $\begin{array}{l}\text { Pct. agreement } 1 / 488.5 \% \\
\text { Cohen's kappa } 1 / 40.698 \\
\text { Scott's pi } 1 / 40.697\end{array}$ & $\begin{array}{l}\text { Pct. agreement } 1 / 497.9 \% \\
\text { Cohen's kappa } 1 / 40.914 \\
\text { Scott's pi } 1 / 40.914\end{array}$ & $\begin{array}{l}\text { Pct. agreement } 1 / 492.9 \% \\
\text { Cohen's kappa } 1 / 40.698 \\
\text { Scott's pi } 1 / 40.696\end{array}$ \\
\hline v12.** & $\begin{array}{l}\text { 'Responsibility' norm displayed } \\
\text { by primary visual male actor } \\
\text { (higher order categories) }\end{array}$ & $\begin{array}{l}\text { Pct. agreement } 1 / 488.9 \% \\
\text { Cohen's kappa } 1 / 40.609 \\
\text { Scott's pi } 1 / 40.600 \\
\text { Pct. } 0.9 \text { reement } 1 / 4.00 \%\end{array}$ & $\begin{array}{l}\text { Pct. agreement } 1 / 492.3 \% \\
\text { Cohen's kappa } 1 / 40.783 \\
\text { Scott's pi } 1 / 40.783 \\
\text { Pct agreement } 1 / 4100 \%\end{array}$ & $\begin{array}{l}\text { Pct. agreement } 1 / 497.9 \% \\
\text { Cohen's kappa } 1 / 40.911 \\
\text { Scott's pi } 1 / 40.911 \\
\text { Pct. agreement } 1 / 4100 \%\end{array}$ & $\begin{array}{l}\text { Pct. agreement } 1 / 492.9 \% \\
\text { Cohen's kappa } 1 / 40.688 \\
\text { Scott's pi } 1 / 40.687 \\
\text { Pct. } 0.11 / 499.2 \%\end{array}$ \\
\hline v13.** & $\begin{array}{l}\text { 'Homophobia' norm displayed by } \\
\text { primary visual male actor }\end{array}$ & $\begin{array}{l}\text { Cohen's kappa } 1 / 4- \\
\text { Scott's pi } 1 / 42\end{array}$ & $\begin{array}{l}\text { Cohen's kappa } 1 / 42 \\
\text { Scott's pi } 1 / 42\end{array}$ & $\begin{array}{l}\text { Cohen's kappa } 1 / 41.000 \\
\text { Scott's pi } 1 / 41.000\end{array}$ & $\begin{array}{l}\text { Cohen's kappa } 1 / 420.000 \\
\text { Scott's pi } 1 / 420.004\end{array}$ \\
\hline v13.** & $\begin{array}{l}\text { (lower order categories) } \\
\text { 'Homophobia’ norm displayed by } \\
\text { primary visual male actor }\end{array}$ & $\begin{array}{l}\text { Pct. agreement } 1 / 4100 \% \\
\text { Cohen's kappa } 1 / 42 \\
\text { Scott's pi } 1 / 42\end{array}$ & $\begin{array}{l}\text { Pct. agreement } 1 / 4100 \% \\
\text { Cohen's kappa } 1 / 42 \\
\text { Scott's pi } 1 / 42\end{array}$ & $\begin{array}{l}\text { Pct. agreement } 1 / 4100 \% \\
\text { Cohen's kappa } 1 / 41.000 \\
\text { Scott's pi } 1 / 41.000\end{array}$ & $\begin{array}{l}\text { Pct. agreement } 1 / 499.2 \% \\
\text { Cohen's kappa } 1 / 420.000 \\
\text { Scott's pi } 1 / 420.004\end{array}$ \\
\hline
\end{tabular}

Notes: Pct. agreement 1/4 percentage agreement; *1/4 including all cases; $* * 1 / 4$ cases including only male primary visual actors. 
Table A2. Percentage and frequency of male primary visual actors across race, described by attribute coding categories, with significance determined through chi-square.

\begin{tabular}{|c|c|c|c|c|c|c|c|c|}
\hline \multirow[b]{2}{*}{ Variable number } & \multirow[b]{2}{*}{ Category } & \multicolumn{2}{|c|}{ Black males } & \multicolumn{2}{|c|}{ White males } & \multirow[b]{2}{*}{ Pearson Chi-square } & \multirow[b]{2}{*}{ df } & \multirow[b]{2}{*}{$\mathrm{p}>$} \\
\hline & & Frequency & Percent & Frequency & Percent & & & \\
\hline \multirow[t]{3}{*}{ v2. } & $\begin{array}{l}\text { Race of primary visual male actor } \\
\text { (higher order categories) }\end{array}$ & 876 & 100.00 & 876 & 100.00 & 112.65 & 1 & 0.01 \\
\hline & Yes & 327 & 37.33 & 549 & 62.67 & & & \\
\hline & No & 549 & 62.67 & 327 & 37.33 & & & \\
\hline \multirow[t]{4}{*}{ v3. } & Social class of primary male visual actor & 327 & 100.00 & 549 & 100.00 & 42.58 & 2 & 0.01 \\
\hline & Lower/working & 43 & 13.15 & 19 & 3.46 & & & \\
\hline & Upper/middle & 254 & 77.68 & 509 & 92.71 & & & \\
\hline & Unclear & 30 & 9.17 & 21 & 3.83 & & & \\
\hline \multirow[t]{8}{*}{ v4. } & $\begin{array}{l}\text { Age of primary visual male actor } \\
\text { (lower order categories) }\end{array}$ & 327 & 100.00 & 549 & 100.00 & 144.00 & 6 & 0.01 \\
\hline & $0-10$ & 3 & 0.92 & 26 & 4.74 & & & \\
\hline & $11-20$ & 51 & 15.60 & 9 & 1.64 & & & \\
\hline & $21-30$ & 195 & 59.63 & 206 & 37.52 & & & \\
\hline & $31-40$ & 34 & 10.40 & 186 & 33.88 & & & \\
\hline & $41-50$ & 33 & 10.09 & 88 & 16.03 & & & \\
\hline & $51-60$ & 4 & 1.22 & 20 & 3.64 & & & \\
\hline & 60 onwards & 7 & 2.14 & 14 & 2.55 & & & \\
\hline \multirow[t]{5}{*}{ v4. } & $\begin{array}{l}\text { Age of primary visual male actor } \\
\text { (higher order categories) }\end{array}$ & 327 & 100.00 & 549 & 100.00 & 29.58 & 3 & 0.01 \\
\hline & $0-20$ & 54 & 16.51 & 35 & 6.38 & & & \\
\hline & $21-40$ & 229 & 70.03 & 392 & 71.40 & & & \\
\hline & $41-60$ & 37 & 11.31 & 108 & 19.67 & & & \\
\hline & 60 onwards & 7 & 2.14 & 14 & 2.55 & & & \\
\hline \multirow[t]{4}{*}{ v5. } & Portrayal of primary visual male actor & 327 & 100.00 & 549 & 100.00 & 9.98 & 2 & 0.01 \\
\hline & Negative & 60 & 18.35 & 77 & 14.03 & & & \\
\hline & Positive & 258 & 78.90 & 432 & 78.69 & & & \\
\hline & Neutral & 9 & 2.75 & 40 & 7.29 & & & \\
\hline
\end{tabular}


Table A2 - continued

\begin{tabular}{|c|c|c|c|c|c|c|c|c|}
\hline \multirow[b]{2}{*}{ Variable number } & \multirow[b]{2}{*}{ Category } & \multicolumn{2}{|c|}{ Black males } & \multicolumn{2}{|c|}{ White males } & \multirow[b]{2}{*}{ Pearson Chi-square } & \multirow[b]{2}{*}{ df } & \multirow[b]{2}{*}{$\mathrm{p}>$} \\
\hline & & Frequency & Percent & Frequency & Percent & & & \\
\hline \multirow[t]{13}{*}{ v6. } & Setting (lower order categories) & 327 & 100.00 & 549 & 100.00 & \multirow{13}{*}{$25 \%$ cell frequencies , 5} & & \\
\hline & Away from home & & & & & & & \\
\hline & Business & 60 & 18.35 & 124 & 22.59 & & & \\
\hline & Outdoors & 138 & 42.20 & 188 & 34.24 & & & \\
\hline & Restaurant / Bar & 8 & 2.45 & 7 & 1.28 & & & \\
\hline & School & 0 & 0.00 & 10 & 1.82 & & & \\
\hline & Other / Unclear & 66 & 20.18 & 24 & 4.37 & & & \\
\hline & Outdoors at home & 1 & 0.31 & 20 & 3.64 & & & \\
\hline & Indoors at home & & & & & & & \\
\hline & Bathroom & 0 & 0.00 & 13 & 2.37 & & & \\
\hline & Kitchen & 4 & 1.22 & 17 & 3.10 & & & \\
\hline & Other / unclear & 4 & 1.22 & 88 & 16.03 & & & \\
\hline & Other / unclear & 46 & 14.07 & 58 & 10.56 & & & \\
\hline \multirow[t]{5}{*}{ v6. } & Setting (higher order categories) & 327 & 100.00 & 549 & 100.00 & \multirow[t]{5}{*}{73.57} & \multirow[t]{5}{*}{3} & \multirow[t]{5}{*}{0.01} \\
\hline & Away from home & 272 & 83.18 & 353 & 64.30 & & & \\
\hline & Outdoors at home & 1 & 0.31 & 20 & 3.64 & & & \\
\hline & Indoors at home & 8 & 2.45 & 118 & 21.49 & & & \\
\hline & Other / unclear & 46 & 14.07 & 58 & 10.56 & & & \\
\hline \multirow[t]{12}{*}{ v7. } & Products (higher order categories) & 327 & 100.00 & 549 & 100.00 & \multirow[t]{12}{*}{ Cell frequencies > 1} & & \\
\hline & Vehicle and related & 55 & 16.82 & 59 & 10.75 & & & \\
\hline & Clothing & 2 & 0.61 & 1 & 0.18 & & & \\
\hline & Domestic goods & 9 & 2.75 & 48 & 8.74 & & & \\
\hline & Electronic and related & 36 & 11.01 & 61 & 11.11 & & & \\
\hline & Food & 103 & 31.50 & 65 & 11.84 & & & \\
\hline & Finance & 34 & 10.40 & 69 & 12.57 & & & \\
\hline & Leisure & 41 & 12.54 & 61 & 11.11 & & & \\
\hline & Personal care & 26 & 7.95 & 131 & 23.86 & & & \\
\hline & Services & 15 & 4.59 & 51 & 9.29 & & & \\
\hline & Security & 0 & 0.00 & 3 & 0.55 & & & \\
\hline & Other & 6 & 1.83 & 0 & 0.00 & & & \\
\hline
\end{tabular}


Table A2 - continued

\begin{tabular}{|c|c|c|c|c|c|c|c|c|}
\hline \multirow[b]{2}{*}{ Variable number } & \multirow[b]{2}{*}{ Category } & \multicolumn{2}{|c|}{ Black males } & \multicolumn{2}{|c|}{ White males } & \multirow[b]{2}{*}{ Pearson Chi-square } & \multirow[b]{2}{*}{ df } & \multirow[b]{2}{*}{$\mathrm{p}>$} \\
\hline & & Frequency & Percent & Frequency & Percent & & & \\
\hline \multirow[t]{5}{*}{ v8. } & $\begin{array}{l}\text { ‘Sexuality’ norm displayed by primary } \\
\text { visual male actor (lower order categories) }\end{array}$ & 327 & 100.00 & 549 & 100.00 & \multirow[t]{5}{*}{$37 \%$ cell frequencies $>5$} & & \\
\hline & $\begin{array}{l}\text { Representation of sexuality: 'no' } \\
\text { Representation of sexuality: ‘ves' }\end{array}$ & 302 & 92.35 & 465 & 84.70 & & & \\
\hline & Successful traditional representation & 24 & 7.34 & 78 & 14.21 & & & \\
\hline & Unsuccessful traditional representation & 1 & 0.31 & 6 & 1.09 & & & \\
\hline & Successful alternative representation & 0 & 0.00 & 0 & 0.00 & & & \\
\hline \multirow[t]{3}{*}{ v8. } & $\begin{array}{l}\text { 'Sexuality’ norm displayed by primary } \\
\text { visual male actor (higher order categories) }\end{array}$ & 327 & 100.00 & 549 & 100.00 & \multirow[t]{3}{*}{11.02} & \multirow[t]{3}{*}{1} & 0.01 \\
\hline & Representation of sexuality: 'no’ & 302 & 92.35 & 465 & 84.70 & & & \\
\hline & Representation of sexuality: ‘yes’ & 25 & 7.65 & 84 & 15.30 & & & \\
\hline \multirow[t]{5}{*}{ v9. } & $\begin{array}{l}\text { ‘Toughness’ norm displayed by primary } \\
\text { visual male actor (lower order categories) }\end{array}$ & 327 & 100.00 & 549 & 100.00 & \multirow[t]{5}{*}{ Cell frequency > 1} & & \\
\hline & $\begin{array}{l}\text { Representation of toughness: 'no' } \\
\text { Representation of toughness: 'yes' }\end{array}$ & 261 & 79.82 & 394 & 71.77 & & & \\
\hline & Successful traditional representation & 33 & 10.09 & 119 & 21.68 & & & \\
\hline & Unsuccessful traditional representation & 33 & 10.09 & 27 & 4.92 & & & \\
\hline & Successful alternative representation & 0 & 0.00 & 9 & 1.64 & & & \\
\hline \multirow[t]{3}{*}{ v9. } & $\begin{array}{l}\text { ‘Toughness' norm displayed by primary } \\
\text { visual male actor (higher order categories) }\end{array}$ & 327 & 100.00 & 549 & 100.00 & \multirow[t]{3}{*}{7.04} & \multirow[t]{3}{*}{1} & 0.01 \\
\hline & Representation of toughness: 'no' & 261 & 79.82 & 394 & 71.77 & & & \\
\hline & Representation of toughness: ‘yes’ & 66 & 20.18 & 155 & 28.23 & & & \\
\hline \multirow[t]{6}{*}{ v10. } & $\begin{array}{l}\text { 'Independence' norm displayed by primary } \\
\text { visual male actor (lower order categories) }\end{array}$ & 327 & 100.00 & 549 & 100.00 & \multirow[t]{6}{*}{14.73} & \multirow[t]{6}{*}{3} & 0.01 \\
\hline & Representation of independence: 'no' & 119 & 36.39 & 222 & 40.44 & & & \\
\hline & Representation of independence: 'yes' & & & & & & & \\
\hline & Successful traditional representation & 151 & 46.18 & 271 & 49.36 & & & \\
\hline & Unsuccessful traditional representation & 48 & 14.68 & 54 & 9.84 & & & \\
\hline & Successful alternative representation & 9 & 2.75 & 2 & 0.36 & & & \\
\hline
\end{tabular}


Table A2 - continued

\begin{tabular}{|c|c|c|c|c|c|c|c|c|}
\hline \multirow[b]{2}{*}{ Variable number } & \multirow[b]{2}{*}{ Category } & \multicolumn{2}{|c|}{ Black males } & \multicolumn{2}{|c|}{ White males } & \multirow[b]{2}{*}{ Pearson Chi-square } & \multirow[b]{2}{*}{ df } & \multirow[b]{2}{*}{$\mathrm{P}>$} \\
\hline & & Frequency & Percent & Frequency & Percent & & & \\
\hline \multirow[t]{3}{*}{ v10. } & $\begin{array}{l}\text { 'Independence’ norm displayed by primary } \\
\text { visual male actor (higher order categories) }\end{array}$ & 327 & 100.00 & 549 & 100.00 & 1.41 & 1 & NS \\
\hline & Representation of independence: 'no’ & 119 & 36.39 & 222 & 40.44 & & & \\
\hline & Representation of independence: ‘yes’ & 208 & 63.61 & 327 & 59.56 & & & \\
\hline \multirow[t]{6}{*}{ v11. } & $\begin{array}{l}\text { ‘Status’ norm displayed by primary } \\
\text { visual male actor (lower order categories) }\end{array}$ & 327 & 100.00 & 549 & 100.00 & $25 \%$ cell frequencies $>5$ & & \\
\hline & Representation of status: 'no’ & 257 & 78.59 & 379 & 69.03 & & & \\
\hline & Representation of status: ‘yes’ & & & & & & & \\
\hline & Successful traditional representation & 58 & 17.74 & 160 & 29.14 & & & \\
\hline & Unsuccessful traditional representation & 3 & 0.92 & 6 & 1.09 & & & \\
\hline & Successful alternative representation & 9 & 2.75 & 4 & 0.73 & & & \\
\hline \multirow[t]{3}{*}{ v11. } & $\begin{array}{l}\text { 'Status’ norm displayed by primary } \\
\text { visual male actor (higher order categories) }\end{array}$ & 327 & 100.00 & 549 & 100.00 & 9.41 & 1 & 0.01 \\
\hline & Representation of status: ‘no’ & 257 & 78.59 & 379 & 69.03 & & & \\
\hline & Representation of status: ‘yes’ & 70 & 21.41 & 170 & 30.97 & & & \\
\hline \multirow[t]{6}{*}{ v12. } & $\begin{array}{l}\text { 'Responsibility’ norm displayed by primary } \\
\text { visual male actor (lower order categories) }\end{array}$ & 327 & 100.00 & 549 & 100.00 & $25 \%$ cell frequencies $>5$ & & \\
\hline & Representation of responsibility: 'no' & 286 & 87.46 & 460 & 83.79 & & & \\
\hline & Representation of responsibility: ‘yes’ & & & & & & & \\
\hline & Successful traditional representation & 40 & 12.23 & 59 & 10.75 & & & \\
\hline & Unsuccessful traditional representation & 0 & 0.00 & 7 & 1.28 & & & \\
\hline & Successful alternative representation & 1 & 0.31 & 23 & 4.19 & & & \\
\hline \multirow[t]{3}{*}{ v12. } & $\begin{array}{l}\text { 'Responsibility’ norm displayed by primary } \\
\text { visual male actor (higher order categories) }\end{array}$ & 327 & 100.00 & 549 & 100.00 & 2.19 & 1 & NS \\
\hline & Representation of responsibility: 'no' & 286 & 87.46 & 460 & 83.79 & & & \\
\hline & Representation of responsibility: ‘yes’ & 41 & 12.54 & 89 & 16.21 & & & \\
\hline
\end{tabular}


Table A2 - continued

\begin{tabular}{|c|c|c|c|c|c|c|c|c|}
\hline \multirow[b]{2}{*}{ Variable number } & \multirow[b]{2}{*}{ Category } & \multicolumn{2}{|c|}{ Black males } & \multicolumn{2}{|c|}{ White males } & \multirow[b]{2}{*}{ Pearson Chi-square } & \multirow[b]{2}{*}{$\mathrm{df}$} & \multirow[b]{2}{*}{$\mathrm{P}>$} \\
\hline & & Frequency & Percent & Frequency & Percent & & & \\
\hline \multirow[t]{5}{*}{ v13. } & $\begin{array}{l}\text { 'Homophobia' norm displayed by primary } \\
\text { visual male actor (lower order categories) }\end{array}$ & 327 & 100.00 & 549 & 100.00 & $50 \%$ cell frequencies $>5$ & & \\
\hline & $\begin{array}{l}\text { Representation of homophobia: 'no’' } \\
\text { Representation of homophobia: ‘yes' }\end{array}$ & 326 & 99.69 & 540 & 98.36 & & & \\
\hline & Successful traditional representation & 0 & 0.00 & 0 & 0.00 & & & \\
\hline & Unsuccessful traditional representation & 0 & 0.00 & 0 & 0.00 & & & \\
\hline & Successful alternative representation & 1 & 0.31 & 9 & 1.64 & & & \\
\hline \multirow[t]{3}{*}{ v13. } & $\begin{array}{l}\text { 'Homophobia' norm displayed by primary } \\
\text { visual male actor (higher order categories) }\end{array}$ & 327 & 100.00 & 549 & 100.00 & $25 \%$ cell frequencies $>5$ & & \\
\hline & Representation of homophobia: 'no' & 326 & 99.69 & 540 & 98.36 & & & \\
\hline & Representation of homophobia: 'yes’ & 1 & 0.31 & 9 & 1.64 & & & \\
\hline
\end{tabular}

Notes: df $1 \frac{1}{4}$ degrees of freedom; NS $1 / 4$ not significant. 